\title{
Absorption and scattering properties of organic carbon versus sulfate dominant aerosols at Gosan climate observatory in Northeast Asia
}

\author{
S. Lim ${ }^{1,2}$, M. Lee ${ }^{3}$, S.-W. Kim ${ }^{4}$, S.-C. Yoon ${ }^{4}$, G. Lee ${ }^{5}$, and Y. J. Lee ${ }^{3}$ \\ ${ }^{1}$ University Grenoble Alpes, LGGE, 38000 Grenoble, France \\ ${ }^{2}$ CNRS, LGGE, 38000 Grenoble, France \\ ${ }^{3}$ Department of Earth and Environmental Sciences, Korea University, Seoul, South Korea \\ ${ }^{4}$ School of Earth and Environmental Sciences, Seoul National University, Seoul, South Korea \\ ${ }^{5}$ Department of Environmental Science, Hankuk University of Foreign Studies, Seoul, South Korea \\ Correspondence to: M. Lee (meehye@ korea.ac.kr)
}

Received: 1 September 2013 - Published in Atmos. Chem. Phys. Discuss.: 19 December 2013

Revised: 21 April 2014 - Accepted: 6 June 2014 - Published: 5 August 2014

\begin{abstract}
Carbonaceous and soluble ionic species of $\mathrm{PM}_{1.0}$ and $\mathrm{PM}_{10}$ were measured along with the absorption and scattering properties and aerosol number size distributions at Gosan Climate Observatory (GCO) from January to September 2008. The daily averaged equivalent black carbon (EBC) measured as aerosol absorption exhibited two types of spectral dependence with a distinct maximum (peak) at either $370 \mathrm{~nm}$ or $880 \mathrm{~nm}$, by which two subsets were extracted and classified into the respective groups (370 and $880 \mathrm{~nm}$ ). The $370 \mathrm{~nm}$ group was distinguished by high organic carbon (OC) concentrations relative to elemental carbon (EC) and sulfate, but sulfate was predominant for the $880 \mathrm{~nm}$ group. The $\mathrm{PM}_{1.0} \mathrm{OC}$ of the $370 \mathrm{~nm}$ group was mainly composed of refractory and pyrolized components that correlated well with $\mathrm{PM}_{1.0} \mathrm{EC} 1$, referred to as char EC, which suggests biofuel and biomass combustion as the source of these $\mathrm{OC}$ fractions, particularly during winter. The scanning electron microscope (SEM) images and the number size distributions implied that aerosols of the $370 \mathrm{~nm}$ group were externally mixed upon transport in fast-moving air masses that passed through the Beijing area in about one day. In contrast, the aerosols of the $880 \mathrm{~nm}$ group were characterized by high sulfate concentrations, and seemed to be internally mixed during slow transport over the Yellow Sea region over approximately 2 to 4 days. The absorption and scattering coefficients of the $880 \mathrm{~nm}$ group were noticeably higher compared to those of the $370 \mathrm{~nm}$ group. The average absorption ångström exponent (AAE) was estimated to be 1.29
\end{abstract}

and 1.0 for the 370 and $880 \mathrm{~nm}$ groups, respectively, in the range $370-950 \mathrm{~nm}$. These results demonstrated that the optical properties of aerosols were intimately linked to chemical composition and mixing state, characteristics determined both by source and atmospheric aging processes. In OC dominant aerosols, absorption was enhanced in the UV region, which was possibly due to refractory and pyrolized OC compounds. Under sulfate dominant conditions, the sulfate coating on $\mathrm{BC}$ particles likely contributed to the absorption of the longer visible light. Consequently, single scattering albedo (SSA) was higher for the $880 \mathrm{~nm}$ group than for the $370 \mathrm{~nm}$ group, emphasizing that the relative abundances of absorbing and scattering constituents are also important in estimating the climate effect of aerosols.

\section{Introduction}

Atmospheric aerosols play an important role in climate change by altering the global radiation balance both directly and indirectly. The relative importance of these processes depends on the chemical composition and size distribution of aerosols (IPCC, 2007). Carbonaceous and sulfate particles are the two most important anthropogenic aerosol constituents influencing climate (Chuang et al., 1997; Haywood and Ramaswamy, 1998; Schult et al., 1997). A positive component of this radiative forcing is largely due to black carbon (BC) produced from pyrolysis during incomplete combustion 
of biomass and fossil fuels (Ramanathan and Carmichael, 2008; Roessler and Faxvog, 1979). The magnitude of the direct radiative forcing from $\mathrm{BC}$ exceeds that due to $\mathrm{CH}_{4}$, suggesting that $\mathrm{BC}$ may be the second most important component of global warming after $\mathrm{CO}_{2}$, in terms of direct forcing (Bond et al., 2013).

However, the definition and measurement techniques for atmospheric BC (commonly referred to as soot) and elemental carbon (EC) have long been subjects of scientific controversy. In general, BC and EC are identified by their different analytical methods: BC is measured using its optical properties, with the main property being strong absorption of visible light with a mass absorption cross section (MAC) at a wavelength of $\lambda=550 \mathrm{~nm}$ above $7.5 \pm 1.2 \mathrm{~m}^{2} \mathrm{~g}^{-1}$ for freshly produced particles (Bond et al., 2013). In contrast, EC is usually determined by thermal methods based on its chemical properties, and is defined as the carbonaceous fraction of particulate matter that can only be gasified by oxidation starting at temperatures above $340^{\circ} \mathrm{C}$ (Petzold et al., 2013). Among the types of $\mathrm{BC}$, the $\mathrm{BC}$ derived from the light-absorption coefficient $\left(\sigma_{\mathrm{ap}}\right)$ using a MAC is called equivalent BC (EBC). Given that this measurement technique detects particles that absorb light, EBC measurements could include other absorbing compounds and possibly lead to slightly different mass concentrations than EC measurements. The light absorption of $\mathrm{BC}$ is generally considered to be weakly dependent on wavelength (Bergstrom et al., 2002). Conversely, other lightabsorbing aerosol components such as organics and dust show stronger dependence on the absorption spectrum that contributes to absorption at shorter wavelengths (Bergstrom et al., 2007; Kirchstetter, 2004). Recent studies have reported that light-absorbing organic carbon that is not black ("brown carbon"), tends to absorb light strongly in the blue and ultraviolet (UV) spectral regions (Andreae and Gelencsér, 2006; Jacobson, 1998, 1999). In the atmosphere, fresh BC ages as it is transported, leading to mixing with other aerosol components such as organics, minerals, and sulfates (Hasegawa and Ohta, 2002). It has been found that organic or sulfate coating around an inner BC core enhances the light absorption of BC by a "lensing" effect (Cross et al., 2010; Lack et al., 2009). Thus, the presence of light-absorbing organics and aerosols, either as intrinsic components of or as coatings on the $\mathrm{BC}$ particles makes it imperative to reassess and redefine $\mathrm{BC}$ and other light-absorbing carbonaceous matter in the atmosphere (Andreae and Gelencsér, 2006).

In regions influenced by various emissions from deserts, oceans, biomass burning, and human and industrial activities, aerosol chemical composition and optical properties are extremely complicated. Therefore, it is critical to understand the link between chemical composition and optical properties, particularly for policy making related to climate change. East Asia is a typical example of one of the regions described above and is one of the strongest $\mathrm{BC}$ emission source regions (Bond et al., 2004, 2013). Here, we examined light-absorbing and scattering properties of aerosols in relation to their major components including carbonaceous and soluble ions using data obtained at GCO located in northeast Asia.

\section{Measurements}

The chemical compositions of $\mathrm{PM}_{1.0}$ and $\mathrm{PM}_{10}$ were measured along with aerosol optical properties and particle number distributions from August 2007 to September 2008 at $\operatorname{GCO}\left(33.17^{\circ} \mathrm{N}, 126.10^{\circ} \mathrm{E}, 70 \mathrm{~m}\right.$ a.s.l. $)$ on Juju island, which is known as an ideal location for monitoring Asian outflows. For this study, a subset of 29 samples was chosen from January to September 2008, for which the measurements of chemical composition, aerosol absorption and scattering, and number size distribution were all available. The sample set included five samples from January, three from February, four from March, eight from April, four from May, one from June, two from August, and two from September 2008. Details of the sampling procedures and methods can be found in Lim et al. (2012).

For $\mathrm{PM}_{1.0}$ and $\mathrm{PM}_{10}$, sampling was conducted once every 6 days, starting at 09:00 LST and lasting for $24 \mathrm{~h}$. Eight inorganic species were determined by using ion chromatography (Dionex 4500, Dionex, USA), and EC and organic carbon (OC) were quantified by the Interagency Monitoring of Protected Visual Environments (IMPROVE) thermal/optical reflectance (TOR) protocol, which produced four OC fractions in a non-oxidizing $\mathrm{He}$ atmosphere $(\mathrm{OC} 1, \mathrm{OC} 2, \mathrm{OC} 3$, and OC4 at temperatures of $120,250,450$, and $550^{\circ} \mathrm{C}$, respectively) and three $\mathrm{EC}$ fractions in an oxidizing atmosphere of $2 \% \mathrm{O}_{2} / \mathrm{He}$ mode (EC1, EC2, and EC3 at 550, 700, and $800^{\circ} \mathrm{C}$, respectively). In the He mode, a fraction of OC was pyrolyzed (OP) and this evolved in the oxidizing atmosphere until the reflected light achieved its initial value. OP is assumed to be originally organic carbon, so OC is considered to be the sum of the four OC fractions and the OP fraction, and $\mathrm{OP}$ is subtracted from the sum of EC fractions.

Light-absorption coefficients $\left(\sigma_{\text {ap }}\right)$ were obtained every $10 \mathrm{~min}$ from the seven wavelength aethalometer measurements (AE-31, Magee scientific Corp., USA) and EBC mass concentrations were derived with the "Magee $\mathrm{BC}$ " calibration factor (Hansen, 2005). The aethalometer collects the aerosol sample on a quartz fiber filter tape and measures the light attenuation of samples at wavelengths covering the UV to the near-IR ranges (i.e., 370, 470, 520, 590, 660, 880, and $950 \mathrm{~nm}$ ). Similar to other filter-based absorption instruments, the aethalometer needs to be corrected for scattering by the fiber filter substrates, scattering of aerosols embedded in the filter, and filter loading by accumulation of light absorbing particles (Collaud Coen et al., 2010). In this study, $\sigma_{\text {ap }}$ was determined by following the correction process presented by Arnott et al. (2005). The absorption ångström exponent (AAE) was determined by statistical regression to fit the $\sigma_{\text {ap }}$ data with a power law equation. The MAC of EBC along wavelengths was calculated by dividing the light absorption 
coefficient by EC mass concentration. The scattering coefficient was obtained from a nephelometer (model 3563, TSI Inc., USA) every $10 \mathrm{~min}$ at three wavelengths: $450 \mathrm{~nm}$, $550 \mathrm{~nm}$, and $700 \mathrm{~nm}$, which were corrected to STP and for truncation according to Anderson and Ogren (1998). The absorption and scattering data were averaged daily for comparison with chemical compositions that were measured daily. Aerosol number size distributions from $10.4 \mathrm{~nm}$ to $469.8 \mathrm{~nm}$ in diameter were measured every $10 \mathrm{~min}$ using a scanning mobility particle sizer (SMPS, model 3034, TSI Inc., USA). The scanning electron microscope (SEM) image was obtained from quartz filters laden with $\mathrm{PM}_{1.0}$ after being coated with platinum and palladium.

\section{Results and discussion}

\subsection{Spectral dependence of absorption on chemical characteristics}

We compared daily averaged EBC concentrations with $\mathrm{PM}_{1.0}$ EC concentrations and examined the spectral dependence of EBC. The EC concentrations of $\mathrm{PM}_{1.0}$ agreed well with EBC at $880 \mathrm{~nm}$, which corresponds to $92 \%$ of $\mathrm{PM}_{1.0}$ EC. At other wavelengths, the EBC concentrations were less than $90 \%$ of $\mathrm{PM}_{1.0}$ EC. The daily averaged EBC concentrations varied along wavelengths, some of which showed clear maxima either at $370 \mathrm{~nm}$ or at $880 \mathrm{~nm}$. The EBC concentrations of the others did not significantly change along wavelengths, but tended to be slightly higher at $660 \mathrm{~nm}$. While the maxima at $370 \mathrm{~nm}$ were apparent regardless of EBC concentration, they were less distinguished at $880 \mathrm{~nm}$ or $660 \mathrm{~nm}$ as EBC concentration decreased. Thus, we only considered EC concentrations higher than mean for the classification of the $880 \mathrm{~nm}$ maximum. Based on the wavelength peak of EBC, five samples were selected for both the 370 and $880 \mathrm{~nm}$ groups. Then, chemical characteristics of each group were compared for major constituents, including EC, OC, sulfate, and inorganic salts. In particular, their relative abundance was distinguished between the two groups such as OC / EC, $\mathrm{OC}$ / sulfate, and EC / sulfate ratios. It is noteworthy that all three ratios were higher for the $370 \mathrm{~nm}$ group than for the $880 \mathrm{~nm}$ group. While the $370 \mathrm{~nm}$ group was characterized by relatively higher OC concentration, sulfate was predominant for the $880 \mathrm{~nm}$ group. However, there was one exception in the $880 \mathrm{~nm}$ group (9 January 2008), in which the OC / EC ratio was high with relatively low ratios of $\mathrm{OC} /$ sulfate and $\mathrm{EC} /$ sulfate. Its maximum absorption was also not as distinct as the other four in the group. Thus, it was excluded and the other four samples were finally classified as the $880 \mathrm{~nm}$ group. The five samples of the $370 \mathrm{~nm}$ and the four samples of the $880 \mathrm{~nm}$ group were collected in winter and spring, respectively (Table 1).

Figure 1a shows the EBC concentrations relative to $\mathrm{PM}_{1.0}$ EC concentrations along wavelengths. Although the concen-
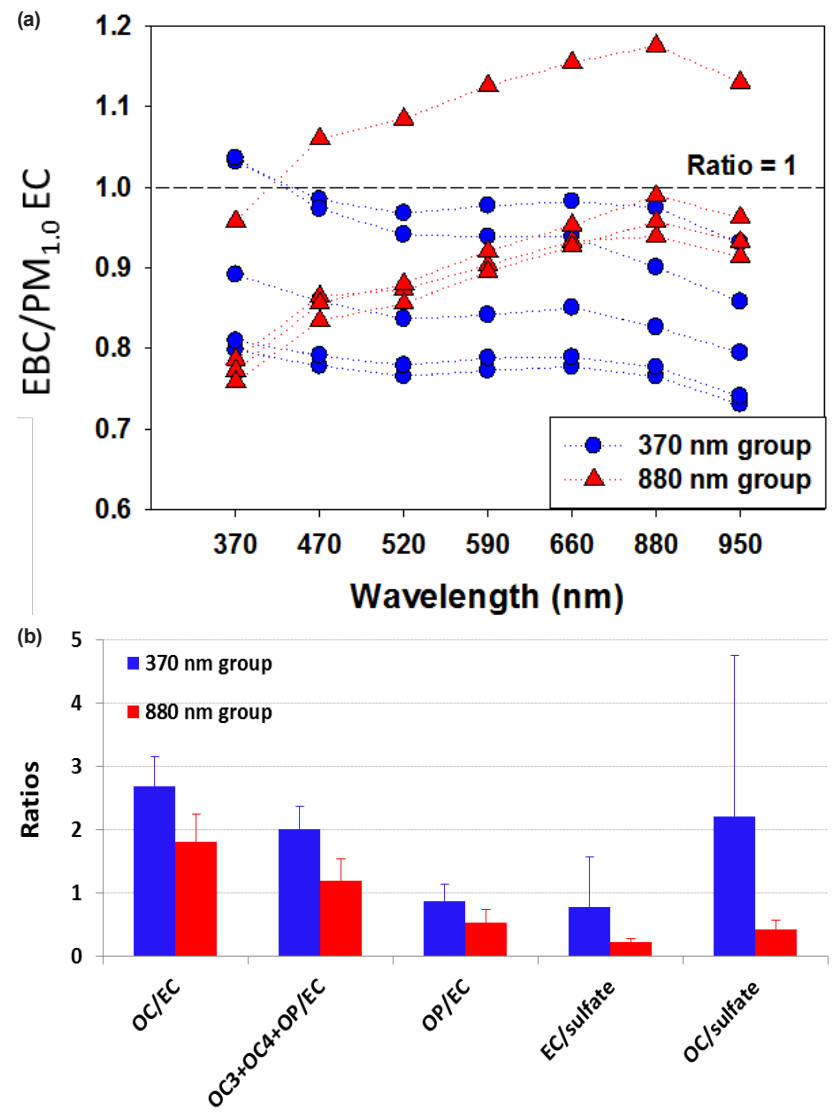

Figure 1. Comparison of the $370 \mathrm{~nm}$ group with the $880 \mathrm{~nm}$ group. (a) $\mathrm{EBC} / \mathrm{PM}_{1.0} \mathrm{EC}$ ratios as a function of wavelength. (b) Ratios of OC / EC, OC3 + OC4 + OP / EC, OP / EC, EC / sulfate, and $\mathrm{OC} /$ sulfate in $\mathrm{PM}_{1.0}$. Ratios are shown as mean values and error bars indicate standard deviation $(1 \sigma)$.

trations of $\mathrm{EBC}$ and $\mathrm{PM}_{1.0} \mathrm{EC}$ were expected to be equal, they were found to be slightly different. The EBC / PM 1.0 EC ratio varied from 0.73 to 1.04 and from 0.76 to 1.18 for the 370 and $880 \mathrm{~nm}$ groups, respectively. For the former, the EBC $/ \mathrm{PM}_{1.0} \mathrm{EC}$ ratio was the highest at $370 \mathrm{~nm}$ and decreased toward $950 \mathrm{~nm}$ by $0.07 \sim 0.18$. For the latter, the EBC $/ \mathrm{PM}_{1.0}$ EC ratio was at its minimum at $370 \mathrm{~nm}$ and gradually increased by $0.15 \sim 0.22$ to its maximum at $880 \mathrm{~nm}$. The following discussion regarding absorption enhancement along wavelength is based on this analysis. The chemical characteristics of the two groups are summarized in Table 1. While EBC concentrations were lower for the $370 \mathrm{~nm}$ group compared to those of the $880 \mathrm{~nm}$ group, OC concentrations were similar in the two groups. The difference in meteorological variables and precursor gases reflect seasonal characteristics of each group. 
Table 1. Comparison of the $370 \mathrm{~nm}$ group and the $880 \mathrm{~nm}$ group.

\begin{tabular}{|c|c|c|c|c|}
\hline & \multicolumn{2}{|c|}{$370 \mathrm{~nm}$ group } & \multicolumn{2}{|c|}{$880 \mathrm{~nm}$ group } \\
\hline Date & \multicolumn{2}{|c|}{ 3, 15, and 27 Jan, 14 Feb, 3 Mar } & \multicolumn{2}{|c|}{11 Mar, 14 and 17 Apr, 21 May } \\
\hline \multicolumn{5}{|l|}{ Meteorological parameters } \\
\hline Wind speed $\left(\mathrm{m} \mathrm{s}^{-1}\right)$ & $7.1-12.6(11.6)^{\mathrm{a}}$ & & $2.6-5.7(4.0)$ & \\
\hline Wind direction & $\mathrm{NW}, \mathrm{N}$ & & SE, NE, NW & \\
\hline Temp. $\left({ }^{\circ} \mathrm{C}\right)$ & $4.4-8.5(5.9)$ & & $10.6-18.6(13.9)$ & \\
\hline RH (\%) & $45-59(53)$ & & $58-79(71)$ & \\
\hline \multicolumn{5}{|l|}{ Precursor gases (ppbv) } \\
\hline $\mathrm{SO}_{2}$ & $1.1-12.4(5.8)$ & & $1.3-9.5(3.9)$ & \\
\hline $\mathrm{CO}$ & $350-746(604)$ & & $458-875(573)$ & \\
\hline $\mathrm{O}_{3}$ & $33-51(40)$ & & $49-82(65)$ & \\
\hline \multicolumn{5}{|l|}{$\mathrm{PM}_{1.0}\left(\mu \mathrm{g} \mathrm{m}^{-3}\right)$} \\
\hline Mass $^{b}$ & 7.42-20.32 (13.47) & & $21.73-26.22(23.36)$ & \\
\hline Ions & $2.80-11.11(6.50)$ & & $11.79-17.80(13.93)$ & \\
\hline $\mathrm{EC}$ & $0.65-2.62(1.61)$ & & $2.08-2.31(2.18)$ & \\
\hline $\mathrm{OC}$ & $1.95-4.92(4.07)$ & & $3.22-5.30(3.95)$ & \\
\hline $\mathrm{OC} 3+\mathrm{OC} 4$ & $0.67-2.69(1.75)$ & & $1.03-1.86(1.47)$ & \\
\hline OP & $0.74-1.93(1.31)$ & & $0.82-1.87(1.15)$ & \\
\hline Sulfate & $0.67-5.88(3.25)$ & & $7.99-12.33(9.83)$ & \\
\hline Nitrate & $0.12-2.43(1.37)$ & & $0.63-1.69(1.07)$ & \\
\hline \multicolumn{5}{|l|}{$\mathrm{PM}_{10}\left(\mu \mathrm{g} \mathrm{m}^{-3}\right)$} \\
\hline Mass $^{\mathrm{b}}$ & $11.85-44.18(29.83)$ & & $39.66-46.91(42.18)$ & \\
\hline Ions & $5.68-20.76(13.72)$ & & $24.97-32.55(27.59)$ & \\
\hline sodium & $0.05-0.21(1.38)$ & & $0.40-0.74(0.52)$ & \\
\hline chloride & $0.63-3.54(2.05)$ & & $0.10-0.25(0.18)$ & \\
\hline magnesium & $0.14-0.53(0.37)$ & & $0.16-0.22(0.19)$ & \\
\hline calcium & $0.13-0.69(0.42)$ & & $0.28-0.58(0.37)$ & \\
\hline $\mathrm{Na}^{+}+\mathrm{Cl}^{-}+\mathrm{Mg}^{2+} \mathrm{Ca}^{2+}$ & $1.40-6.67(4.22)$ & & $1.03-1.46(1.27)$ & \\
\hline EBC & $\mathrm{EBC}\left(\mu \mathrm{g} \mathrm{m}^{-3}\right)$ & Absorption coeff. $\left(\mathrm{Mm}^{-1}\right)$ & $\mathrm{EBC}\left(\mu \mathrm{g} \mathrm{m}^{-3}\right)$ & Absorption coeff. $\left(\mathrm{Mm}^{-1}\right)$ \\
\hline $370 \mathrm{~nm}$ & $0.67-2.09(1.43)$ & $8.48-27.51$ (19.97) & $1.63-1.99(1.78)$ & $20.28-26.40$ (22.69) \\
\hline $470 \mathrm{~nm}$ & $0.64-2.04(1.37)$ & $5.92-19.58(14.15)$ & $1.81-2.21(1.96)$ & $16.72-21.65(18.60)$ \\
\hline $520 \mathrm{~nm}$ & $0.63-2.01(1.34)$ & $5.11-16.88(12.15)$ & $1.86-2.26(2.01)$ & $15.13-19.43(16.68)$ \\
\hline $590 \mathrm{~nm}$ & $0.64-2.03(1.35)$ & $4.43-14.67$ (10.49) & $1.95-2.34(2.09)$ & $13.59-17.33$ (14.93) \\
\hline $660 \mathrm{~nm}$ & $0.64-2.04(1.36)$ & $3.89-12.79(9.19)$ & $2.02-2.40(2.15)$ & $12.26-15.41(13.41)$ \\
\hline $880 \mathrm{~nm}$ & $0.64-2.01(1.33)$ & $2.81-9.13(6.52)$ & $2.09-2.45(2.20)$ & $9.23-11.24(9.91)$ \\
\hline $950 \mathrm{~nm}$ & $0.61-1.92(1.27)$ & $2.49-7.98(5.72)$ & $2.04-2.35(2.14)$ & $8.17-9.78(8.75)$ \\
\hline \multicolumn{5}{|c|}{ Scattering coefficient $\left(\mathrm{Mm}^{-1}\right)$} \\
\hline $450 \mathrm{~nm}$ & $58-257(147)$ & & $257-360(308)$ & \\
\hline $550 \mathrm{~nm}$ & $47-199(113)$ & & $200-278(235)$ & \\
\hline $700 \mathrm{~nm}$ & $34-135(76)$ & & $132-179(150)$ & \\
\hline
\end{tabular}

a The numbers in parentheses are averaged values.

${ }^{\mathrm{b}}$ Of the total mass, eight ionic soluble ions, OC, and EC were measured. Detailed information on chemical composition can be found in Lim et al. (2012).

\subsection{Optical properties in relation to chemical composition}

\subsubsection{Organic carbon dominant regime}

The OC / EC ratio of $\mathrm{PM}_{1.0}$ was higher for the $370 \mathrm{~nm}$ group (2.68) than for the $880 \mathrm{~nm}$ group (1.81) (Fig. 1b). The av- erage OC / EC ratio of the total sample set was 2.26. For the $370 \mathrm{~nm}$ group, the contribution of OC3, OC4, and OP to $\mathrm{PM}_{1.0} \mathrm{OC}$ was noticeable. The higher $\mathrm{PM}_{1.0} \mathrm{OC} / \mathrm{EC}$ ratio of the $370 \mathrm{~nm}$ group was mostly due to the greater contribution of refractory OC, including OC3 and OC4 that are resistant to volatilization and evolve at higher temperatures $\left(450\right.$ and $\left.550{ }^{\circ} \mathrm{C}\right)$, and $\mathrm{OP}$. The average ratio of $\mathrm{PM}_{1.0}$ 
$(\mathrm{OC} 3+\mathrm{OC} 4+\mathrm{OP}) / \mathrm{EC}$ for the $370 \mathrm{~nm}$ group (2.00) was higher than that of the $880 \mathrm{~nm}$ group (1.20) and the total sample set (1.51). The average $\mathrm{PM}_{1.0} \mathrm{OP} / \mathrm{EC}$ was also greater for the $370 \mathrm{~nm}$ group $(0.87)$ than the $880 \mathrm{~nm}$ group (0.53).

In this study, the larger fraction of $\mathrm{PM}_{1.0}$ refractory $\mathrm{OC}$ and $\mathrm{OP}$ against EC (e.g., (OC3 + OC4 + OP) / EC and $\mathrm{OP} / \mathrm{EC}$ in Fig. 1b) was associated with the enhanced ratio of $\mathrm{EBC}$ at $370 \mathrm{~nm}$ to EC, which implied the strong light absorption of aerosols in the UV region. It has been reported that brown carbon shows steeper wavelength dependence and has various origins in the atmosphere, e.g., soil humics, humiclike substances (HULIS), tarry materials from combustion, and bioaerosols (Andreae and Gelencsér, 2006 and references therein). These components are considered to be the class of HULIS (Hoffer et al., 2006; Lukács et al., 2007) which is associated with the water soluble organic carbon (WSOC) fraction with high molecular weight (Miyazaki et al., 2007; Yu et al., 2004). In addition, it has been reported that the WSOC fraction of ambient aerosols is prone to charring, and it accounts for a significant fraction of overall OP (Andreae and Gelencsér, 2006; Yu et al., 2002). In the recent study by Kondo et al. (2011) that evaluated the charring of four kinds of laboratory HULIS, more than half evolved as the $\mathrm{OC}$ fraction resistant to volatilization in the He mode and released in $\mathrm{He} / \mathrm{O}_{2}$ mixtures. Clarke et al. (2007) also argued that the measured refractory $\mathrm{OC}$, for which they used a density of bulk HULIS, remaining at high temperature $\left(400^{\circ} \mathrm{C}\right)$ in thermal analysis was responsible for enhanced shortwave absorption in biomass burning plumes. These studies support the observation that the refractory OC lead to more charring in the He mode and, subsequently, to enhanced OP fractions. In this study, a direct link between refractory OC and HULIS or other light-absorbing organics was not confirmed. However, the higher contribution of refractory OC and OP to total OC was one of the main attributes of the $370 \mathrm{~nm}$ group that showed distinctively enhanced absorption at the UV region.

The ratio of $\mathrm{PM}_{1.0}(\mathrm{OC} 3+\mathrm{OC} 4+\mathrm{OP}) / \mathrm{EC}$ was higher than the median not only for the $370 \mathrm{~nm}$ group, but also for those samples including 20 and 26 February, 23 and 26 April, and 30 May. The absorption and chemical characteristics of these five samples (hereafter " $660 \mathrm{~nm}$ group") were compared with that of the $370 \mathrm{~nm}$ group to see if refractory OC and OP were responsible for the light absorption at short wavelengths. For the $660 \mathrm{~nm}$ group, there were no trends in light absorption with wavelength but the absorption was slightly enhanced at $660 \mathrm{~nm}$. Although the ratio of $\mathrm{PM}_{1.0}$ $(\mathrm{OC} 3+\mathrm{OC} 4+\mathrm{OP}) / \mathrm{EC}$ was similar in the two groups, this ratio in $\mathrm{PM}_{10}$ was much lower for the $370 \mathrm{~nm}$ group (2.60) compared to that of the $660 \mathrm{~nm}$ group (3.64).

In the previous study by Lim et al. (2012), OC3 and OC4 were found predominantly in $\mathrm{PM}_{10}$ when air masses were most likely impacted by soil minerals from dust source regions. For the $660 \mathrm{~nm}$ group, the fraction of $\mathrm{PM}_{10}$ refractory $\mathrm{OC}$ was high and the ratios of $\mathrm{Ca}^{2+} / \mathrm{Mg}^{2+}(1.37)$ and $\mathrm{Ca}^{2+} / \mathrm{Na}^{+}(0.45)$ in $\mathrm{PM}_{10}$ were higher than those of seawa- ter, suggesting substantial influence by soils. The influence of soil was also in accordance with a slight increase in absorption at $660 \mathrm{~nm}$ for the $660 \mathrm{~nm}$ group (Hansen, 2005).

The inorganic salts concentration $\mathrm{Na}^{+}+\mathrm{Ca}^{2+}+\mathrm{Mg}^{2+}+$ $\mathrm{Cl}^{-}$) in the $\mathrm{PM}_{10}$ of the $370 \mathrm{~nm}$ group was 3.3 times higher than that of the $880 \mathrm{~nm}$ group and 1.6 times higher than that of the total sample set. For the $370 \mathrm{~nm}$ group, the ratio of $\mathrm{Cl}^{-} / \mathrm{Na}^{+}$(1.44) was close to that of seawater (1.80) and the ratio of $\mathrm{Mg}^{2+} / \mathrm{Ca}^{2+}$ (1.01) was smaller than that of seawater (3.10) but larger than that of aerosols mainly affected by soil. The ratios of $\mathrm{Na}^{+} / \mathrm{Mg}^{2+}$ (3.79) and $\mathrm{Cl}^{-} / \mathrm{Mg}^{2+}$ (5.54) were also less than those of seawater. These ratios indicate that the inorganic ions of the $370 \mathrm{~nm}$ group were likely derived from salts deposited in dry lakes in northeastern China (Park et al., 2011; Zhang et al., 2012). The air masses of the $370 \mathrm{~nm}$ group were accompanied by strong northerlies or northwesterlies passing the northeastern part of Inner Mongolia (bottom panels in Fig. 4a and b), where salt pans as well as deserts are developed, releasing alkaline soils into the atmosphere. If particular meteorological conditions are met, the inorganic salts deposited onto clay particles could be readily mobilized and transported long distances through the atmosphere by strong winds. Therefore, the coarse particles of the two groups were possibly derived from different sources such as salt deposits and soil minerals, contributing to scattering for the $370 \mathrm{~nm}$ group and to absorption for the $660 \mathrm{~nm}$ group. In addition, the local emission of these inorganic salts should not be disregarded for all samples because Gosan is located right by the sea.

For the $370 \mathrm{~nm}$ group, the inorganic salts of $\mathrm{PM}_{10}$ $\left(\mathrm{Na}^{+}+\mathrm{Ca}^{2+}+\mathrm{Mg}^{2+}+\mathrm{Cl}^{-}\right)$showed a good correlation with the light-scattering coefficient at $550 \mathrm{~nm}\left(R^{2}=0.85\right)$ (Fig. 2a). In addition, $\mathrm{PM}_{10}$ OC was well correlated with the scattering coefficient, while $\mathrm{PM}_{1.0}$ OC showed a weak correlation. The coarse OC possibly originated from salt deposits in dry lakes, and it could be agglomerated with inorganic salts. In this group, OC and inorganic salts were considered as main contributors to light scattering. The chemical effect on light scattering was possibly outweighed by the size effect of the aerosols (Tang, 1996). Mishchenko et al. (2004) also reported that when one of the aerosol components is much larger than the others, it dominates the total optical characteristics of the mixture, especially for semi-externally or externally mixed particles.

In the $370 \mathrm{~nm}$ group, three types of particles recognized by their distinct shapes and sizes seemed to be mixed externally (Fig. 3a). One type consisted of agglomerates that were more irregular in size and shape and bigger than soot agglomerates shown in Fig. 3b, and were thought to be organic particles coating soot (Adachi and Buseck, 2008; Adachi et al., 2010). It is likely that soot particles, being relatively less aged, increased in size through organic coatings under high OC / EC and OC / sulfate conditions. Two other distinct particle shapes were a thin cube and a sphere, thought to be a sea-salt particle and a tar ball, respectively. In particular, a tar 
(a)

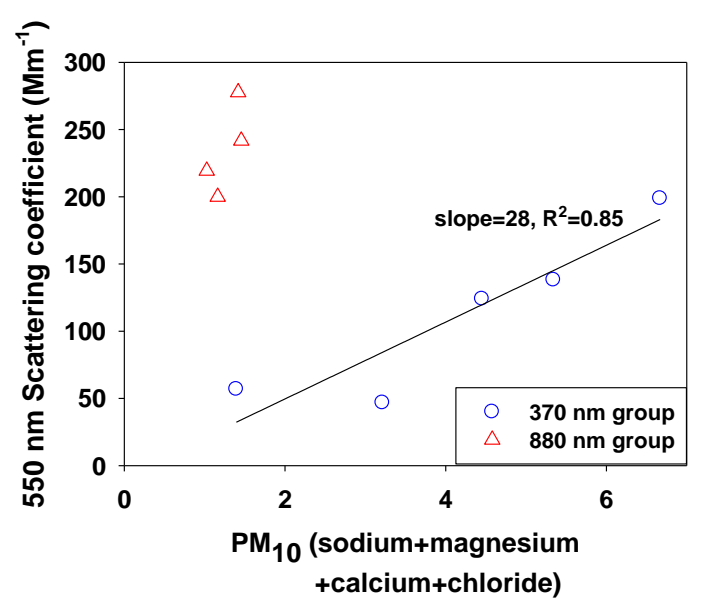

(b)

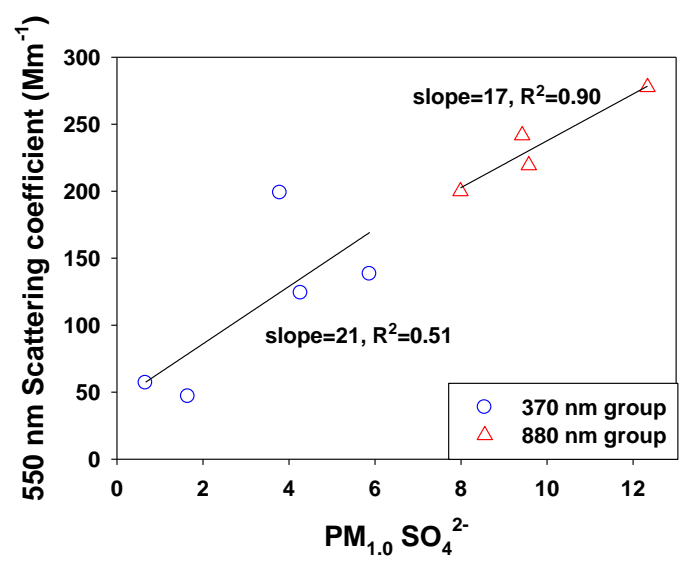

Figure 2. (a) Correlation of $\mathrm{PM}_{10}\left(\mathrm{Na}^{+}+\mathrm{Ca}^{2+}+\mathrm{Mg}^{2+}+\mathrm{Cl}^{-}\right)$ with $550 \mathrm{~nm}$ scattering coefficient. (b) Correlation of $\mathrm{PM}_{1.0}$ sulfate with $550 \mathrm{~nm}$ scattering coefficient. Scattering coefficient data obtained by nephelometer were collected at $10 \mathrm{~min}$ intervals, and were averaged for each day to be compared with our observed PM data. Lines show linear regressions, for which slopes and $R^{2}$ values are given.

ball is considered to possibly be brown carbon (Alexander et al., 2008) as well as an indicator of biomass combustion (Pósfai et al., 2004). It is distinguished in shape and structure from soot aggregates, typically made up of spherules 20 to $60 \mathrm{~nm}$ in diameter, often with an internal structure of curved graphene-like layers (Fig. 3b) (Faeth and Köylü, 1995; van Poppel et al., 2005; Vander Wal and Tomasek, 2004). The air masses of the $370 \mathrm{~nm}$ group underwent fast transport, passing through the Beijing area in about one day, and as a result, inorganic particles being externally mixed with EC and organic aerosol might have been able to play a part in light scattering under low sulfate conditions.
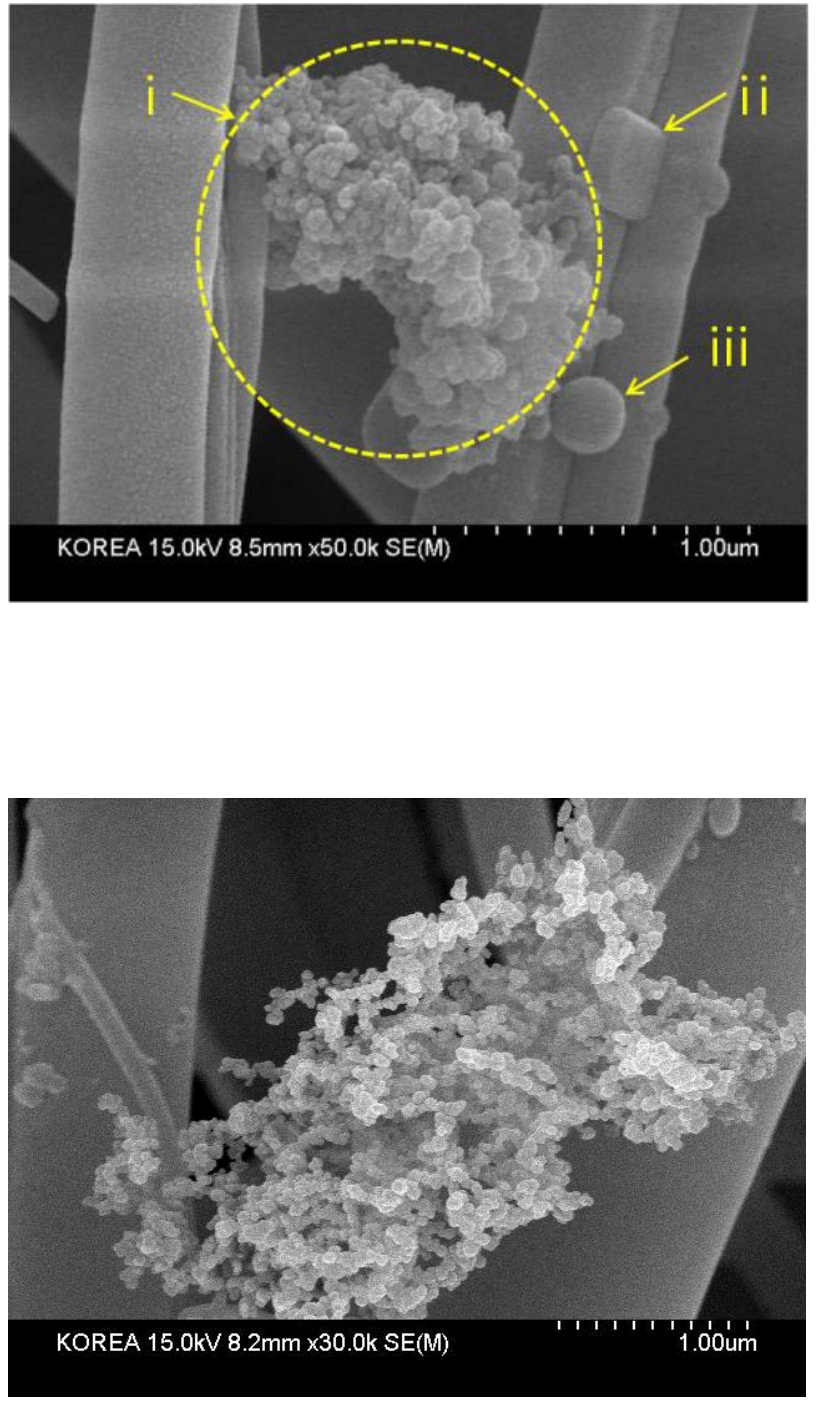

Figure 3. SEM images of ambient particles. (a) Particles in the $370 \mathrm{~nm}$ group, collected on 3 January 2008. Regions and/or particles marked by i, ii, and iii appear to be organic matter, sea salt, and a tar ball, respectively. (b) Aged soot aggregates with larger size and higher compactness in the $880 \mathrm{~nm}$ group, collected on 14 April 2008 .

The majority of samples classified into the $370 \mathrm{~nm}$, $880 \mathrm{~nm}$, or $660 \mathrm{~nm}$ groups were collected under the influence of Chinese outflows in winter and spring and thus carbonaceous compounds were mainly associated with coal and biomass combustion for residential heating (Lu et al., 2011). Their study pointed out biofuel from residential sectors as a predominant source of OC, especially in winter. In our study, for the 370 and $660 \mathrm{~nm}$ groups, the concentrations of $\mathrm{PM}_{1.0}$ EC1, referred to as char EC (Han et al., 2010; Lim et al., 2012) were well correlated with the sum of OC 3 , OC4, and 
(a)

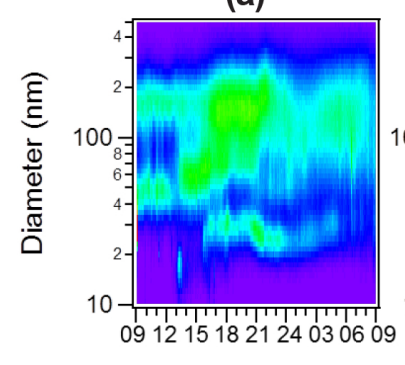

(b)

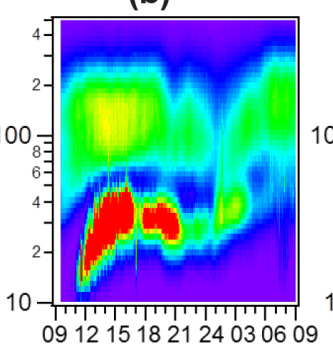

(c)

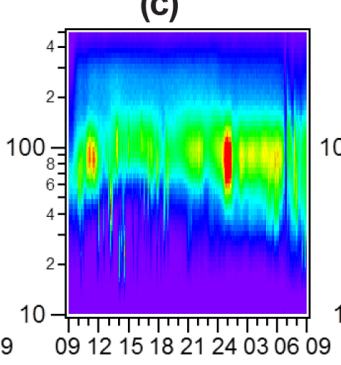

(d)

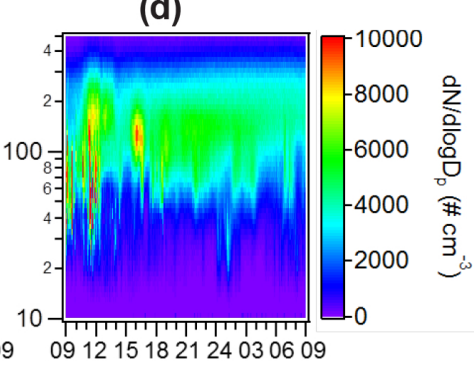

Local Time $(\mathrm{HH})$

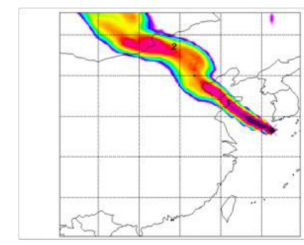

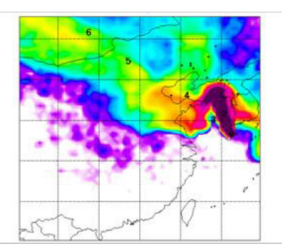
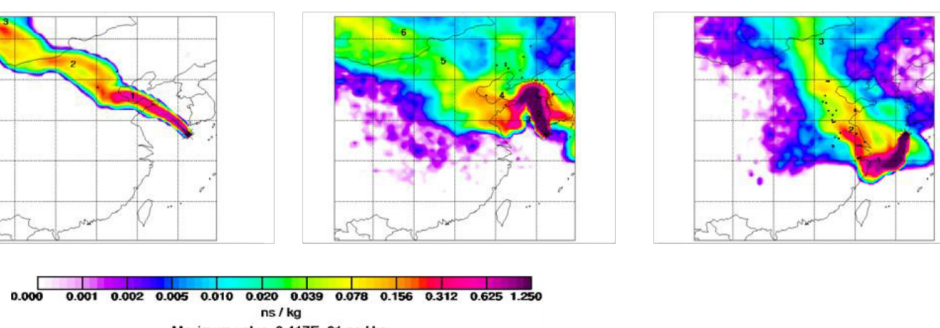

Maximum value $0.417 \mathrm{~kg}+01 \mathrm{ps} / \mathrm{kg}$

Figure 4. Comparison of particle number size distribution (top panels) and air mass trajectories (bottom panels) for the 370 and $880 \mathrm{~nm}$ groups. (a) 3 January and (b) 14 February are included in the $370 \mathrm{~nm}$ group, and (c) 17 April and (d) 21 May are included in the $880 \mathrm{~nm}$ group. Particle number concentrations were measured by SMPS. Air trajectories were obtained by Flexpart model footprint images in (Stohl et al., 2005; http://zardoz.nilu.no/ andreas/STATIONS/GOSAN/index.html). The model output $\left(\mathrm{s} \mathrm{kg}^{-1}\right)$ is a potential emission sensitivity distribution of 40000 particles released in a particular grid cell at the measurement location during the measurement interval and followed backward in time. This is considered proportional to the particle residence time in that cell.

OP in $\mathrm{PM}_{1.0}\left(R^{2}=0.6\right)$, whereas this was not the case for the $880 \mathrm{~nm}$ group $\left(R^{2}<0.1\right)$. The char EC is known to be produced from incomplete combustion at lower temperatures; e.g., biofuel combustion (Han et al., 2010). This implies that the major source of $\mathrm{PM}_{1.0}$ OC for the 370 and $660 \mathrm{~nm}$ groups were biofuel combustion. However, the enhanced absorption of the short wavelengths was observed only for the $370 \mathrm{~nm}$ group. This optical trait of the $370 \mathrm{~nm}$ group would be intimately coupled with chemical characteristics such as high ratios of $\mathrm{OC} / \mathrm{EC},(\mathrm{OC} 3+\mathrm{OC} 4+\mathrm{OP}) / \mathrm{EC}, \mathrm{OP} / \mathrm{EC}$, $\mathrm{OC} /$ sulfate, EC / sulfate in $\mathrm{PM}_{1.0}$, in conjunction with meteorological conditions such as low temperature and high wind speed causing aerosols to be less aged and externally mixed. This also represents favorable conditions for semivolatile organics to be partitioned into the particle phase. In particular, the number distributions of the $370 \mathrm{~nm}$ group showed a distinct peak between 100 and $200 \mathrm{~nm}$ in SMPS measurements (top panels in Fig. 4a and b), which is bigger than freshly produced urban soot particles $(<100 \mathrm{~nm})$ and a size that has been suggested for absorbing particles from biomass burning (100-200 nm) (Schwarz et al., 2008). The agglomerates shown in Fig. 3a could comprise refractory OC or OP as a main component of OC and account for the peak distribution at $100-200 \mathrm{~nm}$ for the $370 \mathrm{~nm}$ group. The ratio of OP to OC was high, particularly in $\mathrm{PM}_{1.0}$ at GCO (Lim et al., 2012). Therefore, the $\mathrm{PM}_{1.0}$ refractory OC and OP of the $370 \mathrm{~nm}$ group are most likely to be responsible for enhanced light absorption in the UV region and to be a constituent part of brown carbon.

\subsubsection{Sulfate dominant regime}

In contrast to the $370 \mathrm{~nm}$ group, the $880 \mathrm{~nm}$ group was distinguished by higher sulfate concentrations, which resulted in lower ratios of $\mathrm{EC} /$ sulfate and $\mathrm{OC} /$ sulfate in $\mathrm{PM}_{1.0}$ (Fig. 1b). The average concentrations of $\mathrm{PM}_{1.0}$ sulfate were $3.25 \mu \mathrm{g} \mathrm{m}^{-3}, 9.83 \mu \mathrm{g} \mathrm{m}^{-3}$, and $5.16 \mu \mathrm{g} \mathrm{m}^{-3}$ for the 370 and $880 \mathrm{~nm}$ groups and the total sample set, respectively. The average ratios of EC/ sulfate and $\mathrm{OC} /$ sulfate in $\mathrm{PM}_{1.0}$ were 0.78 and 2.20 for the $370 \mathrm{~nm}$ group; 0.23 and 0.42 for the $880 \mathrm{~nm}$ group; and 0.37 and 0.90 for the total sample set. The high sulfate concentrations were coupled with stagnant conditions over the Yellow Sea, which supplied sufficient humidity and time for sulfate conversion in Chinese outflows (Lim et al., 2012) (Table 1).

In general, scattering coefficients at $520 \mathrm{~nm}$ were well correlated with sulfate concentrations of $\mathrm{PM}_{1.0}$, which was more pronounced in the $880 \mathrm{~nm}$ group $\left(R^{2}=0.90\right.$; Fig. $\left.2 \mathrm{~b}\right)$. Although the scattering coefficients and sulfate concentrations of the $880 \mathrm{~nm}$ group were greater than those of the $370 \mathrm{~nm}$ group, the scattering coefficient per sulfate mass (slope in Fig. 2b) was less for the $880 \mathrm{~nm}$ group. This result is in accordance with in the findings of previous studies in which $\mathrm{BC}$ incorporated or randomly positioned within the sulfate 
aerosol can lead to absorption enhancement and reduce the expected direct cooling effect due to sulfate (Bond et al., 2013; Chýlek et al., 1995; Fuller et al., 1999; Martins et al., 1998). The mixing of BC with non-absorbing materials such as sulfate has been known to alter the scattering properties of aerosols (Bond et al., 2006).

For the $880 \mathrm{~nm}$ group, BC was likely to be internally mixed with sulfate during the aging processes, which modified the absorption properties of the aerosols and resulted in spectral dependence of EBC (Fig. 1a). The cluster of soot aggregates in Fig. 3b was bigger and more compacted, compared to that in Fig. 3a, which suggests the soot aggregates of the $880 \mathrm{~nm}$ group were more aged (Fu et al., 2012). In other studies, the more aged Chinese air masses were sampled, the more packed soot aggregates were observed (Kang et al., 2012). Although it was not determined if the BC core was surrounded by a well mixed shell including sulfate or simply incorporated into other components, the daily variation of the particle size distribution (top panels in Fig. 4) gives a hint of the mixing state of aerosols, in conjunction with other measurements (e.g., Fig. 3). For the $880 \mathrm{~nm}$ group, the mode and number concentration remained unchanged through the day (top panels in Fig. 4c and d), implying that aerosols were rather internally mixed. In general, the atmospheric BC of remote areas is often internally mixed with other materials such as sulfate (Clarke et al., 1997; Pósfai et al., 1999) through intensive processing due to longer residence times (Hasegawa and Ohta, 2002). From observations near megacities in China including Shanghai, the results of single particle analysis indicate that aerosols were internally mixed during serious pollution events such as haze under prevailing stagnant condition (Fu et al., 2012; Tao et al., 2011; Yang et al., 2012). The air masses classified into the $880 \mathrm{~nm}$ group were slowly transported over the Yellow Sea over 2 to 4 days (bottom panels in Fig. 4c and d), during which BC particles must have been mixed with other types of aerosols such as sulfateforming $\mathrm{BC}$ coatings or intrinsic components.

\subsection{Chemical composition in relation to climate effect of aerosol}

\subsubsection{AAE in relation to organic carbon and sulfate}

The change in EBC concentrations with wavelengths (Fig. 1a) is related to the intrinsic properties of $\mathrm{BC}$ types such as composition, size, mixing state, and source. AAE, denoting the spectral dependence of light absorption, was derived for each group by fitting the measured $\sigma_{\text {ap }}$ at seven wavelengths from $370 \mathrm{~nm}$ to $950 \mathrm{~nm}$ with a power law equation (Fig. 5a). While the AAE of the $370 \mathrm{~nm}$ group was 1.29 $(1.24-1.4)$ for the averaged $\sigma_{\text {ap }}$ ranging from $19.97 \mathrm{Mm}^{-1}$ to $5.72 \mathrm{Mm}^{-1}$, the AAE of the $880 \mathrm{~nm}$ group was close to $1.0(0.95-1.05)$, the theoretical value of $\mathrm{BC}$, with higher $\sigma_{\mathrm{ap}}$ from $22.69 \mathrm{Mm}^{-1}$ to $8.75 \mathrm{Mm}^{-1}$. (a)

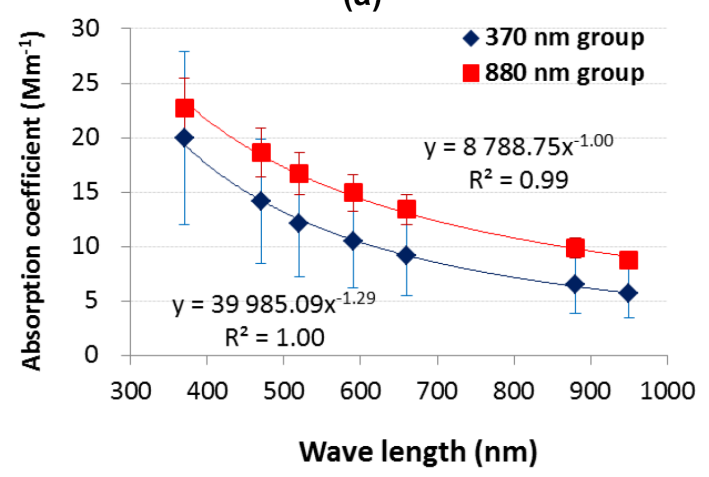

(b)

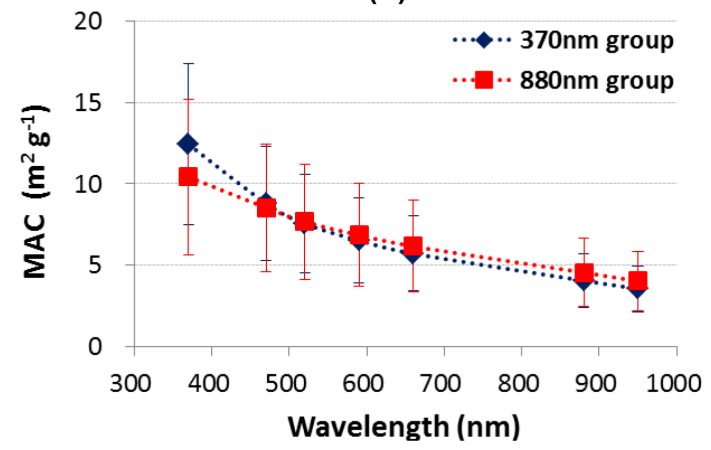

(c)

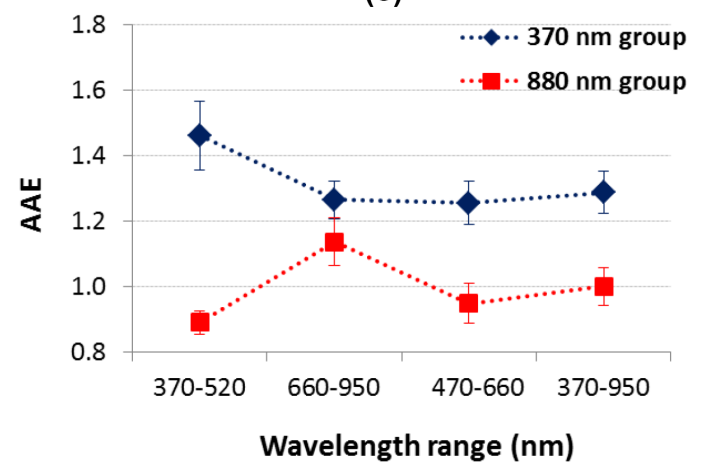

(d)

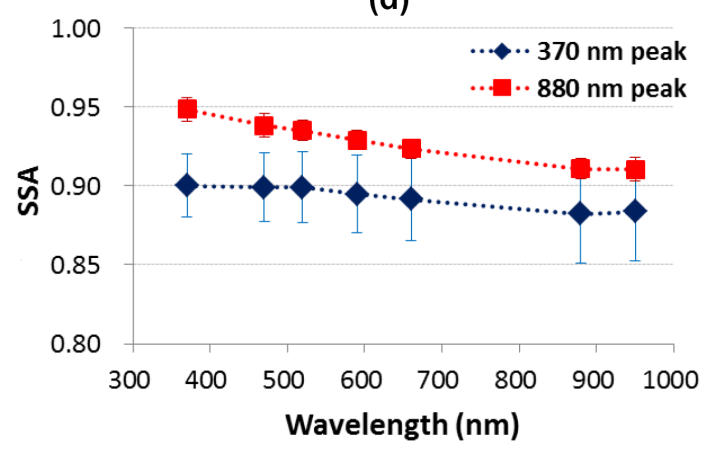

Figure 5. (a) Absorption coefficients $\left(\sigma_{\mathrm{ap}}\right)$ of the 370 and $880 \mathrm{~nm}$ groups and fitted absorption ångström exponent (AAE). (b) Mass absorption cross section (MAC) of the two groups (Please see text for details of the calculation). (c) AAE for the two groups in different wavelength ranges. (d) Single scattering albedo (SSA) along the wavelengths for the two groups. 
In several laboratory and field studies (Kirchstetter, 2004; Schnaiter et al., 2003, 2005), it was observed that BC produced from high-temperature combustion processes (e.g., diesel combustion) has a low spectral dependence with AAE $\approx 1.0$, whereas BC from low-temperature combustion (e.g., biomass burning) exhibits a much stronger spectral dependence with $\mathrm{AAE}>2.0$. Moreover, organic aerosols were reported to contribute to strong light absorption at shorter wavelengths (i.e., UV), leading to higher AAE (Dubovik et al., 1998; Kirchstetter, 2004; Schnaiter et al., 2005). Kirchstetter (2004) demonstrated that in addition to BC, OC contributed considerably to measured light absorption in the UV and visible spectral regions. Theoretical and measurement studies also revealed that coating with scattering aerosol increased the absorption of visible light (Chung et al., 2012; Lack and Cappa, 2010; Schnaiter et al., 2005). Coating BC with scattering materials such as sulfate was reported to increase (Lack and Cappa, 2010) or decrease AAE to less than one (Schnaiter et al., 2005). Lack and Cappa (2010) pointed out that AAE was 1 for sufficiently small BC $(\sim 10 \mathrm{~nm})$ and was subject to change by techniques and analysis methods, thereby suggesting that AAE estimated from measurements should be discussed in view of the analysis method.

The average AAE of the $370 \mathrm{~nm}$ group was 1.29 , which was higher than the diesel BC AAE $(\sim 1.0)$ but lower than biomass burning BC AAE ( 2.0). As discussed above, these samples were influenced by the Beijing plumes, and open biomass burning events were not detected. Consequently, we consider this group to be OC-rich aerosols transported from densely populated areas. In fact, our results lie in the upper limit of AAE (1.0-1.5) derived from OC-rich pollution cases at GCO (Lee et al., 2012).

The AAE of the $880 \mathrm{~nm}$ group had a narrow range between 0.95 and 1.05 with a mean of 1.0 , which was measured in regions close to the source of $\mathrm{BC}$ emitted from high temperature combustion and where externally mixed $\mathrm{BC}$ dominates absorption (Bond et al., 2013; Kirchstetter, 2004; Schnaiter et al., 2003). AAE from measurements was found to be $\sim 1.0$ near an urban roadway (Kirchstetter, 2004) and 0.9-1.3 in samples from urban plumes (Gyawali et al., 2009). In a previous study performed at GCO, AAE of $0.8-1.5$ were derived for aerosols during sulfate rich pollution (Lee et al., 2012), which is in accordance with our result for the $880 \mathrm{~nm}$ group.

To examine the different absorption tendencies of the two groups, we calculated BC MAC along wavelengths for the two groups assuming the measured absorption was attributed solely to BC particles measured as EC (Fig. 5b). Our MAC values were $7.5 \pm 3.0$ and $7.7 \pm 3.5 \mathrm{~m}^{2} \mathrm{~g}^{-1}$ at $520 \mathrm{~nm}$ for the 370 and $880 \mathrm{~nm}$ group, respectively. For the $880 \mathrm{~nm}$ group, the mean EC mass concentration was higher by $35 \%$ and MAC was also higher up to $13 \%$ at near-IR than those of the $370 \mathrm{~nm}$ group. Bond et al. (2013) adopted a value of $7.5 \mathrm{~m}^{2} \mathrm{~g}^{-1}$ at $550 \mathrm{~nm}$ for freshly emitted BC and Bond et al. (2006) suggested ambient MAC values in polluted regions as around $9-12 \mathrm{~m}^{2} \mathrm{~g}^{-1}$. In the study of Lee et al. (2012) performed at GCO, the MAC was $4.2 \pm 1.1 \mathrm{~m}^{2} \mathrm{~g}^{-1}$ for sulfate-pollution event, which is much smaller than that of ours for the $880 \mathrm{~nm}$ group. Liu et al. (2008) claimed that the absorption cross section of BC particles changed by their morphology as they were being packed from chain-like shape, depending on the compactness of a cluster and the size and number of individual particles. This morphological change in $\mathrm{BC}$ particles is coupled with aggregating or internal mixing with hydrophilic particles and coating during aging processes. In particular, the coating of scattering material is known to enhance MAC of carbonaceous core. At GCO, sulfate-rich aerosols are mostly found in aged air masses of Chinese outflows and therefore, the degree of aging associated with $\mathrm{SO}_{2}$ availability was likely to modify optical properties of carbonaceous aerosols. Considering these complex facts, our MAC of $7.7 \pm 3.5 \mathrm{~m}^{2} \mathrm{~g}^{-1}$ for $880 \mathrm{~nm}$ group likely represents the absorption characteristics of aged and sulfate dominant aerosols in the study region. It is also noteworthy to mention that our AAEs were derived from regression method using seven wavelengths, whereas they were calculated using wavelength pairs in Lee et al. (2012). On the other hand, the MAC of the $370 \mathrm{~nm}$ group was similar to those of the polluted OC-rich aerosols in Lee et al. (2012). The OCdominant aerosols of $370 \mathrm{~nm}$ group were less aged than those collected in other periods, for which absorption was highly enhanced in UV region. These results suggest that the MAC of aerosol is greatly dependent on chemical compositions and atmospheric process during aging.

Considering the argument of Lack and Cappa et al. (2010), we compared AAEs calculated for four wavelength ranges: $370-520 \mathrm{~nm}, 470-660 \mathrm{~nm}$, and 660-950 nm (Fig. 5c). For the $370 \mathrm{~nm}$ group, the AAE was increased only at UV region $(370-520 \mathrm{~nm})$ by $15 \%$ relative to that of the visible range $(470-660 \mathrm{~nm})$ with no considerable difference in the other ranges. In contrast, the AAE of the $880 \mathrm{~nm}$ group was decreased by $6 \%$ at UV region $(370-520 \mathrm{~nm})$ but increased by $20 \%$ at IR region $(660-950 \mathrm{~nm})$, compared to that of the visible range $(470-660 \mathrm{~nm})$. These results imply that the enhanced absorption of UV and longer visible light were responsible for the spectral dependence observed in the EBC of the 370 and $880 \mathrm{~nm}$ groups, respectively.

It should also be mentioned that this analysis only considered the most dominant species. Therefore, dominant species such as OC and sulfate are likely responsible for enhanced absorption of UV and longer visible light for the 370 and $880 \mathrm{~nm}$ groups, respectively. The enhanced absorption of OC dominant aerosols in the UV region is consistent with what was observed from other measurements, which highlights the contribution of OC to aerosol spectral dependence. When sulfate was predominant, particularly in aged air masses in northeast Asia, sulfate likely contributed to light absorption at longer visible light probably as a coating on BC particles. 


\subsubsection{SSA in relation to major aerosol composition}

In this study, enhanced light absorption at $370 \mathrm{~nm}$ was found in a fast-moving winter air masses transported from the Beijing region within approximately one day, whereas the high mass absorption at $880 \mathrm{~nm}$ was observed in air masses that slowly passed through the Yellow Sea region (bottom panels in Fig. 4). In the northeast Pacific rim, outflows transported from areas around Beijing tended to show a higher ratio of black carbon to sulfate than those from other parts of China, exerting a strong positive influence on the net warming (Lim et al., 2012; Ramana et al., 2010).

In order to examine how chemical composition alters the optical properties of aerosols, thereby affecting climate, SSA was calculated and compared for the two groups (Fig. 5d). The SSAs for the two groups decreased with increase in wavelength with a greater spectral dependence of the $880 \mathrm{~nm}$ group. Bergstrom et al. (2002) discussed that the SSA of a mixture of $\mathrm{BC}$ and non-absorbing material decreased with wavelength in the solar spectrum, in contrast to most mineral dusts, of which SSA increased with wavelength increase. For this reason, SSA can be used to distinguish aerosol types. The SSA was higher for the $880 \mathrm{~nm}$ group than for the $370 \mathrm{~nm}$ group, despite the higher absorption of the $880 \mathrm{~nm}$ group. For the $370 \mathrm{~nm}$ group, the steady SSA values around 350$500 \mathrm{~nm}$ could be associated with enhanced absorption by light-absorbing OC, in view of MACs in Fig. 5. In the same context, the greater spectral dependence of the $880 \mathrm{~nm}$ group was likely due to absorption enhanced at longer wavelength. This result highlights the importance of considering relative abundance as well as absolute concentrations when estimating radiative forcing of aerosols.

\section{Conclusions}

$\mathrm{PM}_{1.0}$ and $\mathrm{PM}_{10}$ samples were collected daily for the analysis of soluble ions, OC, and EC from January to September 2008 , in conjunction with continuous measurements of absorption and scattering properties and number size distributions of aerosols at GCO. In the comparison of daily averaged EBC with $\mathrm{PM}_{1.0}$ EC concentrations, two types of spectral dependence were identified with clear maxima (peaks) at either $370 \mathrm{~nm}$ or $880 \mathrm{~nm}$, by which two subsets of each five samples were extracted and classified into 370 and $880 \mathrm{~nm}$ groups. The groups were distinguished by the relative abundance of major constituents such as OC/EC, OC/sulfate, and $\mathrm{EC} /$ surface ratios. While the $370 \mathrm{~nm}$ group was characterized by high ratios of OC / EC, OC / sulfate, and EC / sulfate, sulfate was predominant for the $880 \mathrm{~nm}$ group.

In the $\mathrm{PM}_{1.0}$ of the $370 \mathrm{~nm}$ group, the ratios of OC / EC and $(\mathrm{OC} 3+\mathrm{OC} 4+\mathrm{OP}) / \mathrm{OC}$ were higher than those of the $880 \mathrm{~nm}$ group. The main trait of the $370 \mathrm{~nm}$ group was the enhanced light absorption at $370 \mathrm{~nm}$ and greater contribution of refractory OC and OP to total OC, as previous studies reported that increased absorption, particularly in the UV regions, was from light-absorbing organic matter, frequently referred to as brown carbon. In addition, the refractory and pyrolized OC were well correlated with $\mathrm{PM}_{1.0} \mathrm{EC} 1$ (char EC), which indicates biofuel and biomass combustion from residential heating as the source, particularly during winter. Contrastively, the refractory OC in $\mathrm{PM}_{10}$ of the $370 \mathrm{~nm}$ group was likely derived from alkaline soil in dry lakes, contributing to light scattering. The SEM images and number size distributions together with trajectory analysis suggested that these aerosols were externally mixed in fast-moving air masses from the Beijing area passing over Mongolia in approximately one day. In comparison, some samples with a chemical composition similar to the $\mathrm{PM}_{1.0}$ of the $370 \mathrm{~nm}$ group but with different $\mathrm{PM}_{10}$ due to the influence of soil minerals, showed a slight increase in absorption at $660 \mathrm{~nm}$ without a clear tendency in spectral dependence.

In the sulfate dominant regime, the chemical characteristics of the $880 \mathrm{~nm}$ group resulted in the lowest ratios of $\mathrm{EC} /$ sulfate and $\mathrm{OC} /$ sulfate in $\mathrm{PM}_{1.0}$ among all of the measurements. The OC / EC ratio was lower in the $880 \mathrm{~nm}$ group than the $370 \mathrm{~nm}$ group; while OC was similar in the two groups, EC was higher in the $880 \mathrm{~nm}$ group. The scattering coefficients at $520 \mathrm{~nm}$ were higher for the $880 \mathrm{~nm}$ group owing to its high sulfate concentrations in both $\mathrm{PM}_{1.0}$ and $\mathrm{PM}_{10}$. However, the scattering coefficient per sulfate mass was less in the $880 \mathrm{~nm}$ group than in the $370 \mathrm{~nm}$ group. In addition, the aerosols were highly likely to be internally mixed because the mode and number distributions of aerosols remained unchanged through the day and air masses were transported slowly over the Yellow Sea.

The average AAE estimated from $\sigma_{\mathrm{ap}}$ at seven wavelengths from $370 \mathrm{~nm}$ to $950 \mathrm{~nm}$ was $1.29(1.24-1.4)$ for the $370 \mathrm{~nm}$ and $1.0(0.95-1.05)$ for the $880 \mathrm{~nm}$ groups, respectively. AAEs calculated for several different wavelengths confirmed that the absorption was enhanced in the UV or longer visible light regions, leading to the maxima at $370 \mathrm{~nm}$ or $880 \mathrm{~nm}$ in EBC concentrations, respectively. In turn, the dominant species such as OC and sulfate were likely responsible for enhanced absorption of UV and longer visible light for the 370 and $880 \mathrm{~nm}$ groups, respectively. In the OC dominant regime, the enhanced absorption of UV highlights the contribution of OC to aerosol spectral dependence. When sulfate was predominant, particularly in aged air masses in northeast Asia, sulfate likely contributed to light absorption at longer visible light probably as a coating on BC particles. Finally, SSA was higher for the $880 \mathrm{~nm}$ group compared to that of the $370 \mathrm{~nm}$ group, despite the higher absorption of the $880 \mathrm{~nm}$ group. The results of this study demonstrate that the optical properties of aerosols are intimately linked with their composition and mixing state and revealed the importance of the relative abundance as well as absolute concentrations of absorbing and scattering constituents in determining the climate effect of aerosols. 
Acknowledgements. This study was supported by the Korea Meteorological Administration Research and Development Program through CATER 2012-7102. S. Lim specially gives thanks to PanEuropean Gas-AeroSOls-climate interaction Study (PEGASOS) sponsored by the European Commission under the Framework Programme (FP7-ENV-2010-265148) for PhD scholarship and the Korean Ministry of Education and Science Technology for the government scholarship.

Edited by: K. Schaefer

\section{References}

Adachi, K. and Buseck, P. R.: Internally mixed soot, sulfates, and organic matter in aerosol particles from Mexico City, Atmos. Chem. Phys., 8, 6469-6481, doi:10.5194/acp-8-6469-2008, 2008

Adachi, K., Chung, S. H., and Buseck, P. R.: Shapes of soot aerosol particles and implications for their effects on climate, J. Geophys. Res., 115, D15206, doi:10.1029/2009JD012868, 2010.

Alexander, D. T. L., Crozier, P. A., and Anderson, J. R.: Brown carbon spheres in East Asian outflow and their optical properties, Science, 321, 833-836, doi:10.1126/science.1155296, 2008.

Anderson, T. L. and Ogren, J. A.: Determining Aerosol Radiative Properties Using the TSI 3563 Integrating Nephelometer, Aerosol Sci. Technol., 29, 57-69, doi:10.1080/02786829808965551, 1998.

Andreae, M. O. and Gelencsér, A.: Black carbon or brown carbon? The nature of light-absorbing carbonaceous aerosols, Atmos. Chem. Phys., 6, 3131-3148, doi:10.5194/acp-6-3131-2006, 2006.

Arnott, W. P., Hamasha, K., Moosmüller, H., Sheridan, P. J. and Ogren, J. A.: Towards Aerosol Light-Absorption Measurements with a 7-Wavelength Aethalometer: Evaluation with a Photoacoustic Instrument and 3-Wavelength Nephelometer, Aerosol Sci. Technol., 39, 17-29, doi:10.1080/027868290901972, 2005.

Bergstrom, R. W., Pilewskie, P., Russell, P. B., Redemann, J., Bond, T. C., Quinn, P. K., and Sierau, B.: Spectral absorption properties of atmospheric aerosols, Atmos. Chem. Phys., 7, 5937-5943, doi:10.5194/acp-7-5937-2007, 2007.

Bergstrom, R. W., Russell, P. B., and Hignett, P.: Wavelength Dependence of the Absorption of Black Carbon Particles: Predictions and Results from the TARFOX Experiment and Implications for the Aerosol Single Scattering Albedo, J. Atmos. Sci., 59, 567-577, doi:10.1175/15200469(2002)059<0567:WDOTAO>2.0.CO;2, 2002.

Bond, T. C., Doherty, S. J., Fahey, D. W., Forster, P. M., Berntsen, T., DeAngelo, B. J., Flanner, M. G., Ghan, S., Kärcher, B., Koch, D., Kinne, S., Kondo, Y., Quinn, P. K., Sarofim, M. C., Schultz, M. G., Schulz, M., Venkataraman, C., Zhang, H., Zhang, S., Bellouin, N., Guttikunda, S. K., Hopke, P. K., Jacobson, M. Z., Kaiser, J. W., Klimont, Z., Lohmann, U., Schwarz, J. P., Shindell, D., Storelvmo, T., Warren, S. G., and Zender, C. S.: Bounding the role of black carbon in the climate system: A scientific assessment, J. Geophys. Res. Atmos., 118, 5380-5552, doi:10.1002/jgrd.50171, 2013.

Bond, T. C., Habib, G., and Bergstrom, R. W.: Limitations in the enhancement of visible light absorption due to mix- ing state, J. Geophys. Res. Atmos., 111(D20), D20211, doi:10.1029/2006jd007315, 2006.

Bond, T. C., Streets, D. G., Yarber, K. F., Nelson, S. M., Woo, J.-H., and Klimont, Z.: A technology-based global inventory of black and organic carbon emissions from combustion, J. Geophys. Res. Atmos., 109, D14203, doi:10.1029/2003JD003697, 2004.

Chuang, C. C., Penner, J. E., Taylor, K. E., Grossman, A. S., and Walton, J. J.: An assessment of the radiative effects of anthropogenic sulfate, J. Geophys. Res., 102, 3761, doi:10.1029/96JD03087, 1997.

Chung, C. E., Lee, K., and Müller, D.: Effect of internal mixture on black carbon radiative forcing, Tellus B, 64, 1-13, doi:10.3402/tellusb.v64i0.10925, 2012.

Chýlek, P., Videen, G., Ngo, D., Pinnick, R. G., and Klett, J. D.: Effect of black carbon on the optical properties and climate forcing of sulfate aerosols, J. Geophys. Res. Atmos., 100, 16325-16332, doi:10.1029/95jd01465, 1995.

Clarke, A. D., Uehara, T., and Porter, J. N.: Atmospheric nuclei and related aerosol fields over the Atlantic: Clean subsiding air and continental pollution during ASTEX, J. Geophys. Res., 102, 25281, doi:10.1029/97JD01555, 1997.

Clarke, A., McNaughton, C., Kapustin, V., Shinozuka, Y., Howell, S., Dibb, J., Zhou, J., Anderson, B., Brekhovskikh, V., Turner, H., and Pinkerton, M.: Biomass burning and pollution aerosol over North America: Organic components and their influence on spectral optical properties and humidification response, J. Geophys. Res., 112, D12S18, doi:10.1029/2006JD007777, 2007.

Collaud Coen, M., Weingartner, E., Apituley, A., Ceburnis, D., Fierz-Schmidhauser, R., Flentje, H., Henzing, J. S., Jennings, S G., Moerman, M., Petzold, A., Schmid, O., and Baltensperger, U.: Minimizing light absorption measurement artifacts of the Aethalometer: evaluation of five correction algorithms, Atmos. Meas. Tech., 3, 457-474, doi:10.5194/amt-3-457-2010, 2010.

Cross, E. S., Onasch, T. B., Ahern, A., Wrobel, W., Slowik, J. G., Olfert, J., Lack, D. a., Massoli, P., Cappa, C. D., Schwarz, J. P., Spackman, J. R., Fahey, D. W., Sedlacek, A., Trimborn, A., Jayne, J. T., Freedman, A., Williams, L. R., Ng, N. L., Mazzoleni, C., Dubey, M., Brem, B., Kok, G., Subramanian, R., Freitag, S., Clarke, A., Thornhill, D., Marr, L. C., Kolb, C. E., Worsnop, D. R., and Davidovits, P.: Soot Particle Studies-Instrument InterComparison - Project Overview, Aerosol Sci. Technol., 44, 592611, doi:10.1080/02786826.2010.482113, 2010.

Dubovik, O., Holben, B. N., Kaufman, Y. J., Yamasoe, M., Smirnov, A., Tanré, D., and Slutsker, I.: Single-scattering albedo of smoke retrieved from the sky radiance and solar transmittance measured from ground, J. Geophys. Res. Atmos., 103, 31903-31923, doi:10.1029/98JD02276, 1998.

Faeth, G. M. and Köylü, Ü. Ö.: Soot Morphology and Optical Properties in Nonpremixed Turbulent Flame Environments, Combust. Sci. Technol., 108, 207-229, doi:10.1080/00102209508960399, 1995.

Fu, H., Zhang, M., Li, W., Chen, J., Wang, L., Quan, X., and Wang, W.: Morphology, composition and mixing state of individual carbonaceous aerosol in urban Shanghai, Atmos. Chem. Phys., 12, 693-707, doi:10.5194/acp-12-693-2012, 2012.

Fuller, K. A., Malm, W. C., and Kreidenweis, S. M.: Effects of mixing on extinction by carbonaceous particles, J. Geophys. Res. Atmos., 104, 15941-15954, doi:10.1029/1998jd100069, 1999. 
Gyawali, M., Arnott, W. P., Lewis, K., and Moosmüller, H.: In situ aerosol optics in Reno, NV, USA during and after the summer 2008 California wildfires and the influence of absorbing and non-absorbing organic coatings on spectral light absorption, Atmos. Chem. Phys., 9, 8007-8015, doi:10.5194/acp-9-8007-2009, 2009.

Han, Y. M., Cao, J. J., Lee, S. C., Ho, K. F., and An, Z. S.: Different characteristics of char and soot in the atmosphere and their ratio as an indicator for source identification in Xi' an, China, Atmos. Chem. Phys., 10, 595-607, doi:10.5194/acp-10-595-2010, 2010.

Hansen, A. D. A.: Aethalometer-User Manual, Magee Scientific Company, California, USA, 208 pp., 2005.

Hasegawa, S. and Ohta, S.: Some measurements of the mixing state of soot-containing particles at urban and non-urban sites, Atmos. Environ., 36, 3899-3908, 2002.

Haywood, J. M. and Ramaswamy, V.: Global sensitivity studies of the direct radiative forcing due to anthropogenic sulfate and black carbon aerosols, J. Geophys. Res. Atmos., 103, 60436058, doi:10.1029/97JD03426, 1998.

Hoffer, A., Gelencsér, A., Guyon, P., Kiss, G., Schmid, O., Frank, G. P., Artaxo, P., and Andreae, M. O.: Optical properties of humic-like substances (HULIS) in biomass-burning aerosols, Atmos. Chem. Phys., 6, 3563-3570, doi:10.5194/acp-6-3563-2006, 2006.

IPCC: Climate Change 2007: The Physical Science Basis. Contribution of Working Group I to the Fourth Assessment Report of the Intergovernmental Panel on Climate Change, edited by: Solomon, S., Qin, D., Manning, Z., Chen, M., Marquis, K. B., Averyt, M., Tignor, M., and Miller, H. L., 996 pp., Cambridge University Press, Cambridge, UK and New York, NY, USA., 2007.

Jacobson, M. Z.: Studying the effects of aerosols on vertical photolysis rate coefficient and temperature profiles over an urban airshed, J. Geophys. Res., 103, 10593, doi:10.1029/98JD00287, 1998.

Jacobson, M. Z.: Isolating nitrated and aromatic aerosols and nitrated aromatic gases as sources of ultraviolet light absorption, J. Geophys. Res. Atmos., 104, 3527-3542, doi:10.1029/1998JD100054, 1999.

Kang, E., Park, I., Lee, Y. J., and Lee, M.: Characterization of atmospheric particles in Seoul, Korea using SEM-EDX., J. Nanosci. Nanotechnol., 12, 6016-6021, 2012.

Kirchstetter, T. W.: Evidence that the spectral dependence of light absorption by aerosols is affected by organic carbon, J. Geophys. Res., 109, D21208, doi:10.1029/2004JD004999, 2004.

Kondo, Y., Sahu, L., Moteki, N., Khan, F., Takegawa, N., Liu, X., Koike, M. and Miyakawa, T.: Consistency and Traceability of Black Carbon Measurements Made by Laser-Induced Incandescence, Thermal-Optical Transmittance, and Filter-Based Photo-Absorption Techniques, Aerosol Sci. Technol., 45, 295312, doi:10.1080/02786826.2010.533215, 2011.

Lack, D. A. and Cappa, C. D.: Impact of brown and clear carbon on light absorption enhancement, single scatter albedo and absorption wavelength dependence of black carbon, Atmos. Chem. Phys., 10, 4207-4220, doi:10.5194/acp-10-4207-2010, 2010.

Lack, D. A., Cappa, C. D., Cross, E. S., Massoli, P., Ahern, A. T., Davidovits, P., and Onasch, T. B.: Absorption Enhancement of Coated Absorbing Aerosols: Validation of the Photo-Acoustic
Technique for Measuring the Enhancement, Aerosol Sci. Technol., 43, 1006-1012, doi:10.1080/02786820903117932, 2009.

Lee, S., Yoon, S.-C., Kim, S.-W., Kim, Y. P., Ghim, Y. S., Kim, J.H., Kang, C.-H., Kim, Y. J., Chang, L.-S., and Lee, S.-J.: Spectral dependency of light scattering/absorption and hygroscopicity of pollution and dust aerosols in Northeast Asia, Atmos. Environ., 50, 246-254, doi:10.1016/j.atmosenv.2011.12.026, 2012.

Lim, S., Lee, M., Lee, G., Kim, S., Yoon, S., and Kang, K.: Ionic and carbonaceous compositions of $\mathrm{PM}_{10}, \mathrm{PM}_{2.5}$ and $\mathrm{PM}_{1.0}$ at Gosan ABC Superstation and their ratios as source signature, Atmos. Chem. Phys., 12, 2007-2024, doi:10.5194/acp-12-20072012, 2012.

Liu, L., Mishchenko, M. I. and Patrick Arnott, W.: A study of radiative properties of fractal soot aggregates using the superposition T-matrix method, J. Quant. Spectrosc. Radiat. Transf., 109, 2656-2663, doi:10.1016/j.jqsrt.2008.05.001, 2008.

Lu, Z., Zhang, Q., and Streets, D. G.: Sulfur dioxide and primary carbonaceous aerosol emissions in China and India, 1996-2010, Atmos. Chem. Phys., 11, 9839-9864, doi:10.5194/acp-11-98392011, 2011.

Lukács, H., Gelencsér, A., Hammer, S., Puxbaum, H., Pio, C., Legrand, M., Kasper-Giebl, A., Handler, M., Limbeck, A., Simpson, D., and Preunkert, S.: Seasonal trends and possible sources of brown carbon based on 2-year aerosol measurements at six sites in Europe, J. Geophys. Res. Atmos., 112, D23S18, doi:10.1029/2006jd008151, 2007.

Martins, J. V., Hobbs, P. V, Weiss, R. E., and Artaxo, P.: Sphericity and morphology of smoke particles from biomass burning in Brazil, J. Geophys. Res. Atmos., 103, 32051-32057, doi:10.1029/98JD01153, 1998.

Mishchenko, M. I., Liu, L., Travis, L. D., and Lacis, A. A.: Scattering and radiative properties of semi-external versus external mixtures of different aerosol types, J. Quant. Spectrosc. Radiat. Transf., 88, 139-147, doi:10.1016/j.jqsrt.2003.12.032, 2004.

Miyazaki, Y., Kondo, Y., Han, S., Koike, M., Kodama, D., Komazaki, Y., Tanimoto, H., and Matsueda, H.: Chemical characteristics of water-soluble organic carbon in the Asian outflow, J. Geophys. Res., 112, D22S30, doi:10.1029/2007JD009116, 2007.

Park, I., Lim, S., Lee, M., Lee, Y., Kim, J., and Chun, Y.: Ionic compositions of $\mathrm{PM}_{10}$ and reactive gases during Asian dust events in March 2007, J. Atmos., 27, 395-404, 2011.

Petzold, A., Ogren, J. A., Fiebig, M., Laj, P., Li, S.-M., Baltensperger, U., Holzer-Popp, T., Kinne, S., Pappalardo, G., Sugimoto, N., Wehrli, C., Wiedensohler, A., and Zhang, X.-Y.: Recommendations for reporting "black carbon" measurements, Atmos. Chem. Phys., 13, 8365-8379, doi:10.5194/acp-13-83652013, 2013.

Van Poppel, L. H., Friedrich, H., Spinsby, J., Chung, S. H., Seinfeld, J. H., and Buseck, P. R.: Electron tomography of nanoparticle clusters: Implications for atmospheric lifetimes and radiative forcing of soot, Geophys. Res. Lett., 32, L24811, doi:10.1029/2005GL024461, 2005.

Pósfai, M., Anderson, J. R., Buseck, P. R., and Sievering, H.: Soot and sulfate aerosol particles in the remote marine troposphere, J. Geophys. Res., 104, 21685, doi:10.1029/1999JD900208, 1999.

Pósfai, M., Gelencsér, A., Simonics, R., Arató, K., Li, J., Hobbs, P. V., and Buseck, P. R.: Atmospheric tar balls: Particles from biomass and biofuel burning, J. Geophys. Res. Atmos., 109, D06213, doi:10.1029/2003jd004169, 2004. 
Ramana, M. V., Ramanathan, V., Feng, Y., Yoon, S. C., Kim, S. W., Carmichael, G. R., and Schauer, J. J.: Warming influenced by the ratio of black carbon to sulphate and the black-carbon source, Nat. Geosci., 3, 542-545, 2010.

Ramanathan, V. and Carmichael, G.: Global and regional climate changes due to black carbon, Nat. Geosci, 1, 221-227, 2008.

Roessler, D. M. and Faxvog, F. R.: Optoacoustic measurement of optical absorption in acetylene smoke, J. Opt. Soc. Am., 69, 1699-1704, 1979.

Schnaiter, M., Horvath, H., Möhler, O., Naumann, K. H., Saathoff, H., and Schöck, O. W.: UV-VIS-NIR spectral optical properties of soot and soot-containing aerosols, J. Aerosol Sci., 34, 14211444, doi:http://dx.doi.org/10.1016/S0021-8502(03)00361-6, 2003.

Schnaiter, M., Linke, C., Möhler, O., Naumann, K. H., Saathoff, H., Wagner, R., Schurath, U., and Wehner, B.: Absorption amplification of black carbon internally mixed with secondary organic aerosol, J. Geophys. Res. Atmos., 110, D19204, doi:10.1029/2005jd006046, 2005.

Schult, I., Feichter, J., and Cooke, W. F.: Effect of black carbon and sulfate aerosols on the Global Radiation Budget, J. Geophys. Res., 102, 30107-30117, 1997.

Schwarz, J. P., Gao, R. S., Spackman, J. R., Watts, L. A., Thomson, D. S., Fahey, D. W., Ryerson, T. B., Peischl, J., Holloway, J. S., Trainer, M., Frost, G. J., Baynard, T., Lack, D. A., de Gouw, J. A., Warneke, C., and Del Negro, L. A.: Measurement of the mixing state, mass, and optical size of individual black carbon particles in urban and biomass burning emissions, Geophys. Res. Lett., 35, L13810, doi:10.1029/2008GL033968, 2008.
Tang, I. N.: Chemical and size effects of hygroscopic aerosols on light scattering coefficients, J. Geophys. Res. Atmos., 101, 19245-19250, doi:10.1029/96JD03003, 1996.

Tao, S., Wang, X., Chen, H., Yang, X., Li, M., Li, L., and Zhou, Z.: Single particle analysis of ambient aerosols in Shanghai during the World Exposition, 2010: two case studies, Front. Environ. Sci. Eng. China, 5, 391-401, doi:10.1007/s11783-011-0355-x, 2011.

Vander Wal, R. L. and Tomasek, A. J.: Soot nanostructure: dependence upon synthesis conditions, Combust. Flame, 136, 129140, doi:http://dx.doi.org/10.1016/j.combustflame.2003.09.008, 2004.

Yang, F., Chen, H., Du, J., Yang, X., Gao, S., Chen, J. and Geng, F.: Evolution of the mixing state of fine aerosols during haze events in Shanghai, Atmos. Res., 104-105, 193-201, doi:10.1016/j.atmosres.2011.10.005, 2012.

Yu, J. Z., Xu, J., and Yang, H.: Charring Characteristics of Atmospheric Organic Particulate Matter in Thermal Analysis, Environ. Sci. Technol., 36, 754-761, doi:10.1021/es015540q, 2002.

Yu, J. Z., Yang, H., Zhang, H., and Lau, A. K. H.: Size distributions of water-soluble organic carbon in ambient aerosols and its size-resolved thermal characteristics, Atmos. Environ., 38, 1061-1071, 2004.

Zhang, G., Dong, J., Xiao, X., Hu, Z., and Sheldon, S.: Effectiveness of ecological restoration projects in Horqin Sandy Land, China based on SPOT-VGT NDVI data, Ecol. Eng., 38, 20-29, 2012. 